\title{
ПРО ЗАВДАННЯ 3 ВПРОВАДЖЕННЯ ЄВРОПЕЙСЬКИХ СТАНДАРТІВ ТА ДИРЕКТИВ ІЗ ВНУТРІШНЬОЇ ТА ЗОВНІШНЬОЇ ГАРАНТІЇ ЯКОСТІ В СИСТЕМУ ПІДГОТОВКИ ЛІКАРІВ І ПРОВІЗОРІВ У НАЦІОНАЛЬНОМУ МЕДИЧНОМУ УНІВЕРСИТЕТІ ІМЕНІ О. О. БОГОМОЛЬЦЯ
}

В. Ф. Москаленко, О. П. Яворовський, Л. І. Остапюк, В. С. Чешук Національний медичний університет імені О. О. Богомольия

\section{TASKS OF IMPLEMENTATION OF EUROPEAN STANDARDS AND INSTRUCTIONS ON INTERNAL AND EXTERNAL QUALITY ASSURANCE INTO PHYSICIANS' AND PHARMACISTS' TRAINING AT NATIONAL MEDICAL UNIVERSITY BY O. O. BOHOMOLETS}

\author{
V. F. Moskalenko, O. P. Yavorovskyi, L. I. Ostapyuk, V. Ye. Cheshuk \\ National Medical University by O.O. Bohomolets
}

\begin{abstract}
У роботі відображено шестирічний досвід впровадження ECTS в систему підготовки лікарів та завдання щодо покращання менеджменту системи якості відповідно до Європейських стандартів та директив з гарантії якості (ENQA).

The article adduces the six-year experience of the ECTS implementation into the University system of physicians' training and tasks on quality system management improvement in accordance with European standards and instructions on quality assurance (ENQA).
\end{abstract}

Вступ. Модернізація вищої медичної освіти в контексті європейських вимог розпочалась значно раніше набуття нашою державою статусу учасниці Болонського процесу в м. Бергені у травні 2005 р. Упродовж останніх 6 років вищі навчальні медичні заклади України, в тому числі Національний медичний університет імені О. О. Богомольця, активно працювали в напрямі інтеграції медичної освіти і науки України у єдиний Європейський освітній простір відповідно до заходів, передбачених наказом МОЗ України від 22.03.2004 p., № 148 [1]. Особливу увагу приділяли розробці й впровадженню заходів щодо підвищення якості освіти на рівні, який би у майбутньому відповідав міжнародним критеріям. Це тим більше важливо, що у документах, котрі регулюють Болонський процес і які були опубліковані упродовж 19992010 років, якість належить до ключових питань.

Основна частина. У 2011 році 841 випускник медичних факультетів (із них 74 іноземні громадяни), які з 1 вересня 2005 року розпочали навчання за вимогами Європейської кредитно-трансферної системи (ЄКТС), отримають диплом спеціаліста, додаток до диплома вітчизняного зразка та міжнародний додаток до диплома: Diploma Supplement.

За новою методологією навчання (СКТС) i iï технологією - кредитно-модульною системою організації навчального процесу (КМСОНП) в університеті навчаються 7058 (70 \%) студентів медичного, медико-психологічного, стоматологічного і фармацевтичного факультетів.

Модернізація системи підготовки лікарів в Україні, у т. ч. в НМУ зумовила ряд вагомих перетворень в організації навчально-виховногопроцесу на додипломному етапі:

- впровадження нової моделі навчального плану (проект ECTS), в якому назви дисциплін приведено у відповідність до таких в медичних університетах Європи, зменшене тижневе навантаження до 24-26 на-

() В. Ф. Москаленко, О. П. Яворовський, Л. І. Остапюк, В. Є. Чешук 
вчальних годин, в той час як кількість навчальних годин на самостійну роботу студентів зросла до 40-45\%;

- назви кафедр в НМУ приведено у відповідність 3 назвами дисциплін в новому навчальному плані; замість факультетських і госпітальних кафедр створені, відповідно, кафедри внутрішньої медицини, хірургії, педіатрії з наскрізними програмами викладання дисциплін шляхом ротації змістових модулів;

-48 опорних кафедр університету очолили роботу однопрофільних кафедр ВМ(Ф)НЗ України зі створення нового інформаційного та навчально-методичного забезпечення;

- співробітниками базових (опорних) кафедр НМУ разом $з$ однопрофільними кафедрами України розроблено більше 200 типових навчальних програм 3 нормативних дисциплін та елективних курсів; видано 170 підручників та близько 300 навчальних посібників нового покоління;

- впроваджено такі принципи СКТС, як кредитність, модульність, методичне консультування, діагностичність, індивідуалізація навчання, суб' єктносуб' єктні відносини між викладачем і студентом, що значно збільшує їх взаємну відповідальність і зацікавленість у позитивних результатах;

- впроваджено стандартизовану систему оцінювання результатів навчання студентів, яка мотивує їх до систематичної роботи, оскільки результати поточного контролю є вагомою частиною підсумкової оцінки з навчальної дисципліни; впроваджене ранжування студентів за шкалою СКТС $з$ присвоєнням оцінок “A”, “B”, “C”, “D”, “E”;

- значно посилено роботу із створення резерву на посади викладача за рахунок залучення на кафедри талановитої молоді з числа випускників за критеріями відбору: висока успішність, активна участь у наукових гуртках, конференціях, олімпіадах, наявність наукових публікацій, вільне володіння іноземними мовами і комп'ютерною технікою.

На підставі вищесказаного можна зробити висновок, що ВНМЗ України, в тому числі НМУ імені О. О. Богомольця, виконали вимоги Програми проведення педагогічного експерименту щодо впровадження кредитно-модульної системи організації навчального процесу у вищих навчальних закладах IIIIV рівнів акредитації, яка затверджена наказом МОН України від 23.01.2004 р., № 48 та відповідними наказами MO3 України з питань реалізації положень Болонської декларації у системі вищої медичної та фармацевтичної освіти.
2010 рік було визначено країнами-учасницями Болонського процесу роком завершення створення Європейського простору вищої освіти. В той же час комюніке, прийняті міністрами освіти у Льовені/Лувен-ля-Ньов (2009 р.) [2] та Будапешті/Відні (2010 р.) [3], відмітили, що Європейський простір вищої освіти ще повністю не сформувався. Проте було відмічено такі досягнення за 10 років розбудови єдиного Свропейського освітнього простору:

- розробка національних рамок кваліфікацій відповідно до європейських вимог;

- часткова реалізація принципу мобільності студентів та викладачів;

- опанування навчальними закладами нової методології та технології навчання: Свропейської кредитно-трансферної системи;

- запровадження навчання, орієнтованого на студента.

Комюніке в Льовені/Лувен-ля-Ньов та Будапешті/ Відні $(2009,2010)$ визначили такі пріоритети та завдання:

- продовжити процес створення Свропейського простору вищої освіти до 2020 року;

- як мінімум до 2020 року 20 \% випускників повинні пройти період навчання або практику за кордоном;

- необхідно глибоко проаналізувати впровадження Болонського процесу, прислухаючись до критики 3 боку викладачів і студентів, працювати над його вдосконаленням;

- запровадити в освіті країн-учасниць Болонського процесу стандарти і рекомендації щодо забезпечення якості у Свропейському просторі вищої освіти.

Процес подальшого удосконалення системи підготовки лікарів на європейських засадах передбачає переосмислення шестирічного досвіду їі модернізації за новою методологією і технологією навчання ЄКТС, а також використання цього досвіду на якісно новому рівні.

Вагомим досягненням Болонського процесу є визначення стандартів якості вищої освіти в країнах Свропи. Важливим є те, щооцінка якості за Свропейськими стандартами буде грунтуватись не на тривалості або змісті навчання, а на компетенціях, що набули випускники.

Рішення Колегії МОН України від 2 квітня 2009 року визначає такі завдання для ВНЗ України з підвищення якості освіти:

- вжити заходів щодо подальшого вдосконалення системи внутрішнього моніторингу якості вищої освіти і запровадити у всіх вищих навчальних закладах 
моніторинг якості освітніх послуг з урахуванням оцінок студентства;

- поширити практику оцінки діяльності викладача вищого навчального закладу студентами;

- створити сектор моніторингу впровадження якості освітніх послуг у навчальних закладах.

Наказом НМУ № 144 від 01 .04. 2010 створено сектор моніторингу якості освіти в складі навчально-методичного відділу, пріоритетним завданням якого $є$ створення в університеті сучасної системи менеджменту якості.

У той же час формування національної системи контролю якості освіти сьогодні не може не враховувати порівняльних критеріїв, механізмів і методів їх оцінки відповідно до вимог ENQA (European Association for Quality Assurance - Свропейська асоціація гарантії якості у вищій освіті) [4].

ENQA розроблено три групи Свропейських стандартів і директив, що стосуються внутрішньої гарантії якості у ВНЗ, зовнішньої гарантії якості та стандартів і директив для акредитаційних агентств.

Європейські стандарти та директиви з внутрішньої гарантії якості у ВН3 передбачають наявність у закладах вищої освіти таких компонентів: політики і відповідних процедур гарантій якості, стратегії постійного іiі підвищення, визначення відповідної ролі в цих процесах студентства, оцінювання за прозорими та об' єктивними критеріями успішності студентів як одного 3 найбільш важливих елементів у вищій освіті. Особливу увагу приділяють наявності у ВНЗ механізмів встановлення компетентності та необхідної кваліфікації викладачів, дієвих засобів морального та матеріального заохочення кращих з них, а також відсторонення від викладання недостатньо компетентних викладачів.

Стандарти і директиви, що стосуються внутрішньої гарантії якості уВНЗ, передбачають постійний моніторинг і періодичні перевірки програм, які повинні бути релевантними цілям навчання, а також участь студентів упроцедурах гарантії якості. Ресурси навчання і підтримка студентів повинні знаходитись у вільному доступі, постійно покращуватись за пропозиціями студентів.

Значну увагу приділяють у стандартах проведенню вищими навчальними закладами регулярного самообстеження, як обов'язкового елементу для забезпечення ефективної гарантії якості. Це тим більше важливо, що Європейські стандарти і директиви із зовнішньої гарантії якості у ВНЗ обов'язково враховують ефективність процесів внутрішньої оцінки якості в навчальних закладах.
Свропейські стандарти та директиви гарантії якості регламентують, що “... відповідно до принципу інституційної автономії основна відповідальність за забезпечення якості лежить на кожному з ВНЗ. Це є основою для реальної підзвітності академічної системи якості”'.

Адміністрація та керівники структурних підрозділів НМУ, проаналізувавши чинну традиційну систему забезпечення якості освіти, а також сучасні методики, процеси і ресурси, необхідні для удосконалення системи менеджменту якості в університеті, створили Перспективний комплексний план розвитку НМУ імені О. О. Богомольця (2011-2017 рр.), в якому викладено стратегію, політику, процедури щодо постійного вдосконалення якості.

Концептуальним напрямом у галузі освіти, як передбачено "Перспективним комплексним планом розвитку ... (2011-2017 рр.)”, є утримання лідерських позицій університету в сфері підготовки та забезпеченні конкурентоспроможності фахівців, їх відповідності сучасним вимогам динамічного розвитку ринку праці. Забезпечення європейської якості освіти та подальше входження в світове освітнє середовище буде здійснюватись через виконання таких завдань:

- досягнення відповідності освітніх послуг державним стандартам і європейським вимогам до якості підготовки фахівців;

- впровадження в університеті системи управління якістю освітньої діяльності на основі ідеології загального управління якістю та стандарту ДСТУ ISO - 9001:2008 з метою підготовки до сертифікування системи управління якістю;

- подальше впровадження компетентнісної моделі підготовки лікарів і провізорів на основі цілісної системи знань, розумінь, вмінь, навичок, практичних здібностей у вирішенні професійних завдань, впровадження адекватних сучасних методів оцінювання;

- створення умов впровадження концепції якості підготовки фахівців на основі трикутника знань “освіта-наука-інновації";

- створення інноваційної гнучкої технології планування та організації навчального процесу, орієнтованої на індивідуалізацію навчання, стимулювання творчої самостійної роботи студентів;

- розробка концептуальних підходів та впровадження в навчально-методичну діяльність університету інноваційних форм і методів навчання, які враховують психологічний портрет сучасного студента, лікаря (провізора)-інтерна; 
- впровадження інноваційних технологій та методів навчання, заснованих на досягненнях науки, інформаційних і дистанційних освітніх технологіях;

- забезпечення варіативності форм навчання на основі інтеграції вітчизняного та зарубіжного досвіду та впровадження інноваційних підходів, реалізації сучасних методик телематичної та дистанційної освіти в контексті органічного доповнення традиційних (денної та заочної) форм освітньої діяльності;

- впровадження інноваційних підходів до мовної підготовки викладачів і студентів, досягнення необхідного рівня володіння однією іноземною мовою, в перспективі - двома; читання лекцій і проведення занять іноземною мовою для вітчизняних студентів;

- створення навчально-виробничих комплексів 3 інтегрованими навчальними планами із закладами I-III рівнів акредитаціі;

- формування системи програм додаткової професійної вищої освіти (правової, менеджменту в медицині та фармації, бізнес-освіти);

\section{Література}

1. Про заходи щодо реалізації положень Болонської декларації у системі вищої медичної та фармацевтичної освіти : наказ МОЗ України № 148 від 22.03.2004.

2. Комюніке Конференції Міністрів європейських країн, відповідальних за сферу вищої освіти, Льовен та ЛювенЛя-Ньов, 28-29 квітня 2009 р.
- створення мережі інноваційних навчально-виробничих лабораторій (навчально-виробнича аптека, центр набуття практичних навичок);

- здійснення системного моніторингу освітньої діяльності університету з метою постійного удосконалення системи менеджменту якості;

- впровадження системи атестації науково-педагогічних працівників з врахуванням їх досягнень на інституційному, державному та міжнародному рівнях iз диференційованими формами морального та матеріального заохочення.

Висновок. Зазначені в Перспективному комплексному плані розвитку НМУ імені О. О. Богомольця (2011-2017 рр.) завдання відповідають вимогам Концепції діяльності університету і Свропейським стандартам та директивам з внутрішньої гарантії якості, їх виконання буде постійно контролюватись, а ефективність цих процесів буде оцінюватись під час самообстеження 3 позицій вітчизняних і міжнародних стандартів.

3. Комюніке Конференції Міністрів європейських країн, відповідальних за сферу вищої освіти, Будапешт-Відень, 1112 березня $2010 \mathrm{p}$.

4. (C) European Association for Quality Assurance in Higher Education, 2005 Helsinki. 